\title{
THE CHARACTERISTICS OF GRAYLING BIOTOPES
}

\author{
V. DYK \\ University of Veterinary Science, 61242 Brno
}

Received May 26, 1983

\begin{abstract}
Dyk V.: The Characteristics of Grayling Biotopes. Acta vet. Brno, 53, 1983: 71 - 80 .

The present study analyzes the biotopes of the grayling (Thymallus thymallus Linnaeus, 1758) in the Elbe and Danube river basins from the viewpoint of hydrography, temperature, chemical and saprobic indicators. A wider ecological valency of this species was proved, not yet fully utilized. Further, the grayling is an important bioindicator of the trend in the quality of water-courses in submoutainous areas, uplands and, under the dams, also of the lowlands. The characterized conditions in the grayling biotopes are a starting point for veterinary medicine when improving diagnosis of diseases and their prevention. Along with river management they reveal great economic, leisure-time and sporting reserves.
\end{abstract}

Grayling, ecological valency, bioindicator, intensification of river management.

The grayling biotopes can be characterized and defined ,,in a model way" using hydrography, hydrochemistry and hydrobiology. A new factor of existence was found to be the influence of artificial dam lakes improving the prospects of the grayling also in the lower altitudes.

Not enough attention has been paid to the life inveronment of the grayling in river basins of Central Europe. In our country it was as early as the end of the 19th century that the ichthyologist Frič promted studies of the life and requirements of the grayling. Its ecology was elaborated in detail in the classic work of Sabanějev (1898, 1970). Berg (1948) and Bajkov (1927) studied the systematics of grayling.

The Scandinavian author Ekman (quot. from Thienemann, 1926) stated that the grayling once considerably retreated from glaciers and did not return until after the Glacial Ages, using the Danube route. Im Scandinavia lake form of the fish developed. Thienemann (1926) was reluctant to decide which of the Czech cold-water fish belonged to the mixed glacial fauna and which came later, during the first, still cold, post-glacial times. According to Ekman's more recent investigations it is necessary to classify the grayling among the original European fauna because it could survive the glacial ages in the south. However, it is certain that it is an immigrant from the east and north-east during the early post-glacial period. The results of zoogeographical investigations quoted are closely connected with the present life environment of the grayling as well.

In his survey of fish of this country, which was very instructive in its time, Doležal (1898) wrote that the grayling could be found in places where the trout decreased - in the ,lower rivers". In the 6th edition of his valuable work Borne (1922) characterized grayling biotopes as follows: ,The grayling lives in the bigger Alpine streams and rivers, swiftly running, with stony, and gravel bottom, and because it does not like spring water, it does not penetrate upwards so much as the trout with which it partly lives together, and partly occurs also in the lower barb zones." „F ischer (1920) published the first ecological and biocoenotic study about graylings from Central Europe, from the Diemel stream, a tributary of the river Weser in the Rhine rifer basin, springing in an altitude of $630 \mathrm{~m}$. Tej čka $(1933)$ and D yk $(1954,1956,1958)$ repeatedly devoted their attention to the biotopic characteristics. Of the more recent works, very important is that of Kosto ma rov's team (1957), Zelinka (1950, 1959), Kupka (1966), Holčík and Hensel (1972) among others. Komárek (1942), among others, drew attention to the penetration of the grayling up to the sources of rivers in the Eastern Carpathian Mts. 
The author studied grayling biotopes beginning in 1935 (Otava river), especially in those river basins where it was possible to stay for more days or be able to return repeatedly, or to stay for a longer period (Belá in Liptovský Hrádok, 1938, 1956). Even holiday angling, e. g. on the river Moravice, provided many valuable data. During Kostomarov's complex investigations of the river Moravice, a very rare opportunity arose to confront several pieces of knowledge with the participants of this research team. As a starting point served also reliable data of fish researchers from the period of the critical disappearance of the grayling after the war, of Válek (1946). The acquired knowledge of younger research workers investigating the influence of dams on the lower courses, i. e. Peñáz, Zelinka, etc., completed the picture of the biotopes. Kupka (1966) reported on the prosperity of the grayling from extremely unfavourable parts of the warming-through rivers of the slopes (Bečva river). This report together with verbal communication on the experiences of the outstanding practitioner Nieslanik (1956) from northwest Slovakia completed relatively significantly the picture of grayling biotopes.

\section{Results}

Hydrography of grayling waters of Czechoslovakia

From the complex of abiotic factors, some hydrographic data, i. e. Dzubákov's (1972), help characterize the grayling waters. The river Belá in the Váh river basin was chosen as the first model mountain stream; the grayling lives here up to an altitude of $1000 \mathrm{~m}$ autochthonously, together with the brown trout and miller's thumb, in the lower course also with other fish species (Dyk 1958).

According to its size the river Belá belongs to the IIIrd order of streams, its river basin amounts to $244.303 \mathrm{sq} . \mathrm{km}$, it runs $36.3 \mathrm{~km}$, the coefficient of area divided by the length ${ }^{2}$ is 0.18 , forest precentage of the banks is $40 \%$.

The river basin of Belá near Podbansko where the occurrence of grayling begins is $93.50 \mathrm{sq} . \mathrm{km}$, precipitations $1950 \mathrm{~mm}$, losses $415 \mathrm{~mm}$, runoff $1175 \mathrm{~mm}$, coefficient of runoff 0.74 , special runoff [1 (discharge) sq . km] 38.29, discharge $3.48 \mathrm{~m}^{3} / \mathrm{sec}$.

Mean monthly discharges (1931-1960):

$\begin{array}{llllllllllll}\text { I } & \text { II } & \text { III } & \text { IV } & \text { V } & \text { VI } & \text { VII } & \text { VIII IX } & \text { X } & \text { XI } & \text { XII } \\ 1.29 & 1.07 & 1.33 & 3.90 & 8.16 & 6.49 & 5.67 & 3.90 & 3.07 & 2.48 & 2.80 & 1.94 \mathrm{~m}^{3} / \mathrm{sec} .\end{array}$

Degree of water pollution: Ist class, excellent water. In the main characteristics of the water regime the author indicated the river Belá as a water course passing to the montane "snow type".

The indicators show the possibility of existence of graylings in rough conditions, with a lower intensity of feed uptake during the year (turbid, high water), wintering under minimum discharge, spawning in the month of maximum discharge (May), and under frequent effects of soft and acidulous melt waters.

As the second model we used the river Moravice lying in the moderate European zone, in the Odra river basin. Vostrčil and Losos (1957) state that the discharge maximum occurs as early as in February, whereas the mean monthly discharges during the remaining part of the year have a decreasing tendency down to minimum values in the autumn and winter. During April spawning the graylings leave for the warmer tributaries of the open slopes, or they strip $1-2$ weeks later in the Moravice melt waters. In some rainy and stormy years the discharge rate considerably increases even as late as in July reducing the safety and develop- 
ment of fry as well as of the supply and availability of feed, thus decreasing the possibility of intensive feed uptake and decrease of growth increment.

Peňáz (1966) reports that the maximum discharge in the river Svratka, which is an upland type of grayling and trout river, occurs from the beginning till the end of March $\left(6 \mathrm{~m}^{3} / \mathrm{sec}\right.$.). Due to the Vírská dam there is a certain specifity in the middle part of the course for life conditions of the grayling.

From these three different illustrations it is evident that the water rate of the grayling waters in Czechoslovakia, their mean and maximum discharges, their distribution in the individual seasons, connection of the river with the whole river basin from the hydrographical viewpoint, considerably differ and to a great extent determine, or, in some anomalous years limit, the development of grayling populations.

Regime of water temperature

An important indicator is the water temperature, both during the whole year and mainly during the spawning period, but also during the whole vegetation period when the activity of grayling is increased. Dam reservoirs, warming the rivers up to the winter months, considerably effect the possibility of feed uptake, namely in its benthos component, and enable full feeding of the graylings for the wintering period.

The measurements of Vostrčil and Losos (1957) illustrate the thermal regime of the grayling river Moravice on the slopes, performed during complex research

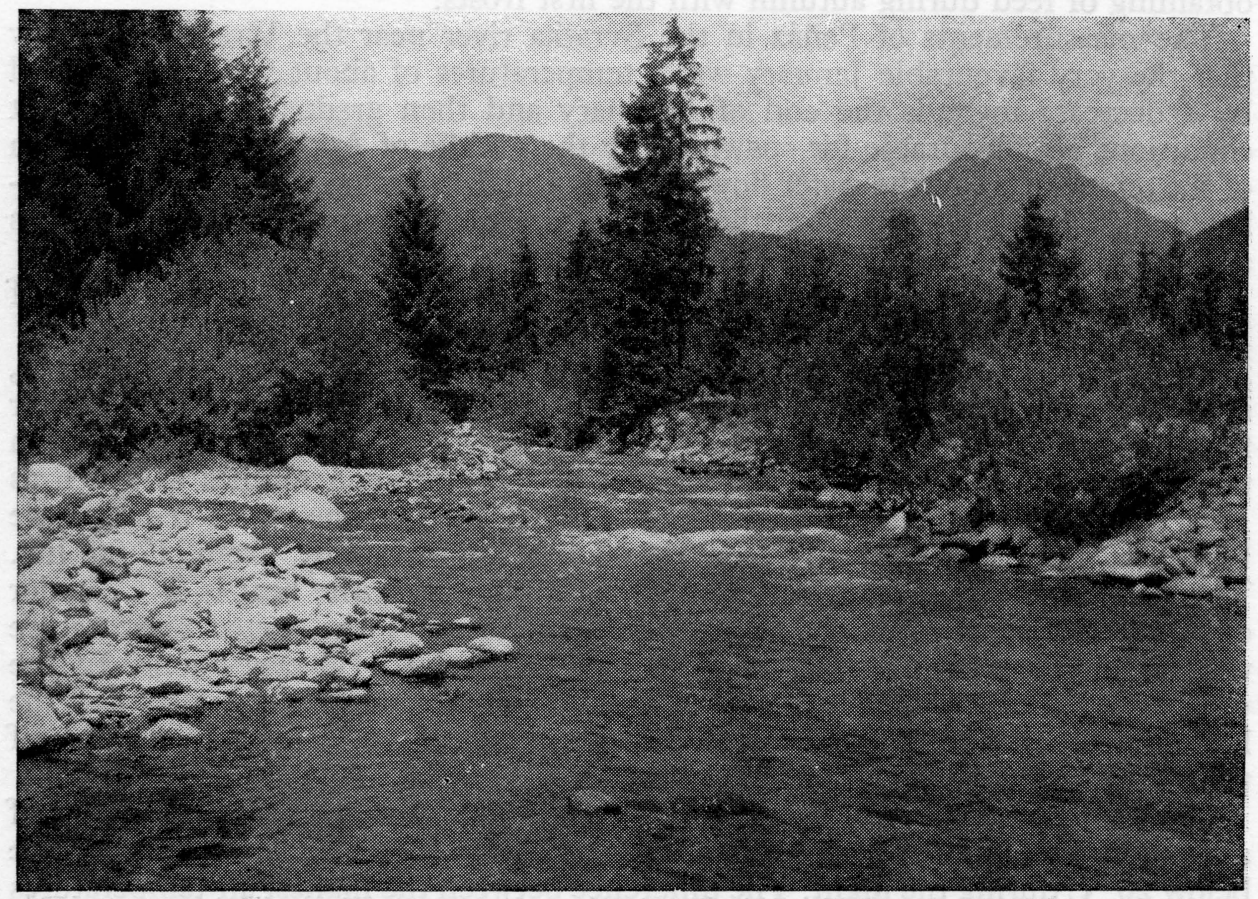

Fig. 1. Belá river near Podbansko (tributary of the river Váh) with grayling mountain biotopes. 
Moravice near Karlovec

Table 1

\begin{tabular}{|c|c|c|c|c|c|c|c|c|c|c|}
\hline Date & 23. 3 . & 8. 5. & 26. 6 . & 18. 8. & 27. 9. & 6. 4. & 21. 7 . & 7. 9. & 27. 10 . & 25.11. \\
\hline $\begin{array}{l}\text { Water } \\
\text { Air }\end{array}$ & $\begin{array}{r}3.2 \\
11.9\end{array}$ & $\begin{array}{l}5.3 \\
3.8\end{array}$ & $\begin{array}{l}15.5 \\
19.5\end{array}$ & $\begin{array}{l}16.1 \\
19.8\end{array}$ & $\begin{array}{l}0.1 \\
0.7\end{array}$ & $\begin{array}{l}4.5 \\
4.4\end{array}$ & $\begin{array}{l}11.4 \\
18.2\end{array}$ & $\begin{array}{l}14.2 \\
18.7\end{array}$ & $\begin{array}{l}4.5 \\
7.4\end{array}$ & $\begin{array}{l}0.0^{\circ} \mathrm{C} \\
0.3^{\circ} \mathrm{C}\end{array}$ \\
\hline
\end{tabular}

Moravice below Kružberk

\begin{tabular}{|c|c|c|c|c|c|c|c|c|c|c|}
\hline Date & 21.3. & 7. 5. & 24.6. & 18.8. & 23. 11 . & 5. 4. & 19.7. & 6. 9. & 26. 10 . & 24. 11 . \\
\hline $\begin{array}{l}\text { Ware } \\
\text { Air }\end{array}$ & $\begin{array}{r}4.4 \\
11.9\end{array}$ & $\begin{array}{r}9.8 \\
10.1\end{array}$ & $\begin{array}{l}21.3 \\
19.2\end{array}$ & $\begin{array}{l}18.7 \\
16.1\end{array}$ & $\begin{array}{l}4.0 \\
3.7\end{array}$ & $\begin{array}{l}7.1 \\
9.8\end{array}$ & $\begin{array}{l}16.7 \\
19.0\end{array}$ & $\begin{array}{l}21.1 \\
21.8\end{array}$ & $\begin{array}{l}9.6 \\
9.7\end{array}$ & $\begin{array}{r}0.1{ }^{\circ} \mathrm{C} \\
-0.5^{\circ} \mathrm{C}\end{array}$ \\
\hline
\end{tabular}

in 1953 and 1954 in the coldest upper course, where summer temperatures do not exceed $15^{\circ} \mathrm{C}$, and under the Kružberk dam.

It is evident that the effect of melt waters from the Hrubé Jeseniky Mts. prevented the water temperature to increase enough to enable the spawning of grayling in April or May during two consequent years. On the contrary, under the Kružberk dam, the water temperature in April and May was above $7{ }^{\circ} \mathrm{C}$, which is known to be a temperature stimulating the graylings to start spawning. Distinctly evident is also the favourable effect of the dam on the possibilities of intensive obtaining of feed during autumn with the first frosts.

The measurements of Peňáz in the Svratka river near the Virská dam show that the very favourable January water temperatures of about $5^{\circ} \mathrm{C}$ are followed by a decrease towards the end of February and then gradual increase so that conditions are favourable for spawning by the middle of April. The culmination of the temperature of the water flowing from the dam occurs in July and September and is $10^{\circ} \mathrm{C}$ (at this time the temperature of the water at the tributary is around $15^{\circ} \mathrm{C}$ and beginning from September it decreases).

In dependence on the summer temperatures of the water the classification of Dyk (1956) can be used, dividing grayling waters into two types:

The montane type of water flowing down from altitudes of about $1000 \mathrm{~m}$, supplied by torrents of the purely trout ,zones“. The water courses rich in water flow down through mountain valleys to altitudes of $650-500 \mathrm{~m}$. The maximum temperature of water in July and August in the afternoon reaches as much as $18.0^{\circ} \mathrm{C}$. The water temperature being as much $27^{\circ} \mathrm{C}$. The water temperature begins to decrease gradually from $16.00 \mathrm{hrs}$, more rapidly from $17.00 \mathrm{hrs}$. The daily fluctuation from morning till evening during the heat is $5{ }^{\circ} \mathrm{C}$, under cloudy weather only $2-3^{\circ} \mathrm{C}$ (Dyk 1956). In hot days the water temperature usually increases from 10.00 to $14.00-15.00 \mathrm{hrs}$ by $1^{\circ} \mathrm{C}$ every hour. In the upper margin of grayling occurrence the daily fluctuations are smaller and the highest temperature of water usually does not exceed $10^{\circ} \mathrm{C}(\mathrm{e} . \mathrm{g}$. in torrents of the Tatra Mountains).

The submontane type of water flowing in altitudes of about $500 \mathrm{~m}$ and lower of a maximum water temperature of as much as $23^{\circ} \mathrm{C}$ which often does not decrease below $20^{\circ} \mathrm{C}$ during the night. The difference between the highest air temperatures of as much as $33^{\circ} \mathrm{C}$ and the water temperature is $10^{\circ} \mathrm{C}$. With cooler nights in the second half of August, the water temperature reaches $17^{\circ} \mathrm{C}$ only. 
The nightly stabilization of relatively high temperatures of water during permanent heat waves which decreased by only $3-3.5^{\circ} \mathrm{C}$ as regards daily temperatures, may effect the existence of the grayling, increase their susceptibility to infections and aggravate their oxygen supply so that the grayling looses interest in intensive feed collection from the river bottom.

Kupka (1966) found that graylings stocked in the deforestated region of the Horní Bečva river tolerated the considerable summer warming of water very well.

A similar situation was investigated during a particularly hot summer in August 1952 in the river Moravice where the water temperature in the morning was $16^{\circ} \mathrm{C}$, at noon, however, a full $20^{\circ} \mathrm{C}$, and towards the evening increased by a further $2-3{ }^{\circ} \mathrm{C}$, so that the difference between the morning and evening temperatures was as much as $7.5^{\circ} \mathrm{C}$. In similar conditions the fish lost interest in feed in the afternoon hours but was not completely suppressed even under these virtually critical conditions.

In this connection general data are given of the value of dissolved oxygen in water courses of the IInd class of water cleanness under various discharges and percentage of saturation according to Zelinka (1959):

\begin{tabular}{|c|c|c|c|c|c|c|c|c|c|}
\hline \multirow{3}{*}{$\begin{array}{l}\text { Class of } \\
\text { cleanness } \\
\text { II }\end{array}$} & \multicolumn{6}{|c|}{ Oxygen dissolved in $\mathrm{mg} / \mathrm{l} \mathrm{O}_{2}$} & \multicolumn{3}{|c|}{ Saturation in $\%$} \\
\hline & \multicolumn{3}{|c|}{ low discharge } & \multicolumn{3}{|c|}{ incr. discharge } & \multicolumn{2}{|c|}{$\begin{array}{c}\text { low } \\
\text { discharge }\end{array}$} & $\begin{array}{l}\text { incr. } \\
\text { discharge }\end{array}$ \\
\hline & $\min$. & $\max$. & average & $\min$. & $\max$. & average & $\min$. & $\max$. & average \\
\hline & 6.2 & 14.3 & 9.8 & 8.1 & 12.3 & 9.7 & 52 & 130 & 80 \\
\hline
\end{tabular}

\section{Chemical composition of grayling waters}

More detailed information about the chemical composition of these waters was obtained when carrying out measures for saving the grayling, performed by the Central Fishing Organization in 1946. Válek ivestigated water samples from those parts of rivers where the grayling still occurred; he studied the main hydrochemical indicators and compared them with the conditions in the rivers where the grayling had become extinct.

As can be seen in Table 2, the $\mathrm{pH}$ varied from 6.2 to 7.6 and did not differ from waters where the grayling had become extinct. The carbonate hardness, expressed in German scale, and the alkalinity connected with it, showed mostly soft waters with $4^{\circ}$, even thought the grayling lived and reproduced in some biotopes also in harder waters of as much as $7^{\circ}$. The consumption of $\mathrm{KMNO}_{4}$ shows a low content of organic matter, even though exceptions were noticed in the polluted sections to which the grayling adapted to a tolerable limit. The occurrence of dissolved oxygen was sufficient so that it has not been separately evaluated.

Válek could justifiably conclude his analyses in stating that grayling waters in Bohemia and Moravia are specifically characterized by an individual, even though variable chemical composition.

From the viewpoint of drastically applied anthropogenic influences Sedlmayer (1937) studied the pollution of the upper Moldau (Vltava) river and stated the river as a montane one draining off mainly rain water from the forests of the Sumava Mts. and extensive peat bogs. Before the water is polluted by paper and pulp mill wastes and by water from housing estates, which destroyed a former continu- 
ous grayling section $100 \mathrm{~km}$ long, it is very clean before Loučovice because, with the exception of ammonia nitrogen and sludge, it corresponds with the English classification (below Frymburk in 1953 there was sludge 4.7, ammonia nitrogen 0.3 , nitrate nitrogen 0.58 , chlorine 4.65 , oxygen consumption 0.82 ).

Table 2

Válek's chemical analysis of grayling water from 1946

\begin{tabular}{|c|c|c|c|c|c|}
\hline River and site of sampling & $\begin{array}{c}\text { Consumption } \\
\text { of } \mathrm{KMnO}_{4} \\
\mathrm{mg}\end{array}$ & $\begin{array}{l}\text { Carbonate } \\
\text { hardness }\end{array}$ & Alkality & $\mathrm{pH}$ & $\mathrm{Fe}$ \\
\hline Otava (Sušice) & 61.9 & 0.67 & 0.24 & 6.4 & - \\
\hline Pstružná & 30.3 & 2.0 & 0.71 & $\begin{array}{l}0.4 \\
6.9\end{array}$ & - \\
\hline Otava (Žichovice) & 31.6 & 1.6 & 0.58 & 6.6 & - \\
\hline Otava (Horaždovice) & 30.9 & 1.49 & 0.53 & 6.7 & traces \\
\hline Blanice (Vodňany) & 39.1 & 1.89 & 0.67 & 6.8 & - \\
\hline Studená Vltava & 24.6 & 0.77 & 0.27 & 6.4 & - \\
\hline Teplá Vltava & 32.2 & 1.08 & 0.38 & 6.6 & _- \\
\hline Lužnice (Suchdol) & 53.08 & 1.7 & 0.62 & 6.6 & - \\
\hline Úhlava (Dubová Lhota) & 35.4 & 1.23 & 0.44 & 6.2 & traces \\
\hline Metuje & 17.69 & 7.1 & 2.5 & 7.4 & - \\
\hline Divoká Orlice & 18.3 & 3.8 & 1.36 & 7.4 & - \\
\hline Jizera (Trutnov) & 41.7 & 2.58 & 0.92 & 6.7 & traces \\
\hline Kamenice (Žel. Brod) & 19.9 & 2.58 & 0.92 & 6.9 & traces \\
\hline Bečva (Zašov) & 41.7 & 3.78 & 1.35 & 7.3 & traces \\
\hline Bečva (Rouždky) & 41.4 & 7.84 & 2.81 & 7.3 & - \\
\hline Moravice (Rýmařov) & 39.8 & 3.78 & 1.35 & 6.9 & traces \\
\hline Moravice (Vítkov) & 41.1 & 3.64 & 1.31 & 7.1 & traces \\
\hline Moravice (Kružberk) & 41.7 & 3.1 & 1.11 & 7.5 & traces \\
\hline Moravice (Harta) & 35.4 & 3.25 & 1.16 & 6.9 & traces \\
\hline Cerná Opavice (Brantice) & 31.0 & 2.3 & 0.82 & 6.9 & traces \\
\hline
\end{tabular}

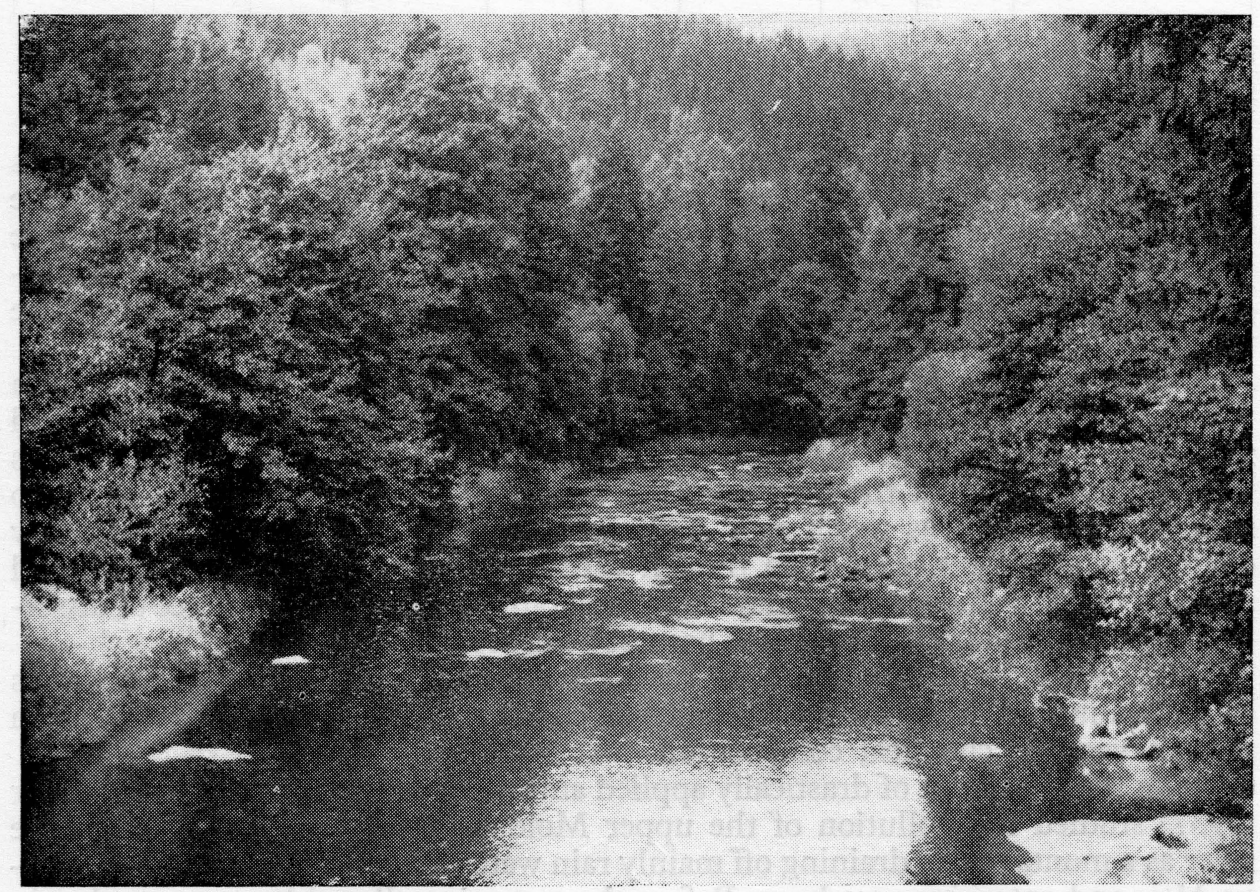

Fig. 2. River Moravice on Karlova Pláň near Bruntál showing grayling submontane biotopes. 
Vostrčil (1957) recorded very detailed hydrochemical data about the grayling sections of the river Moravice, including some negative factors of civilization which increase eutrophization. At the beginning section of grayling occurrence the water is clear, oligosaprobic, type, IInd class of cleannes, the BSK values do not exceed $2 \mathrm{mg} \mathrm{O} /$ /iter, it is saturated to oversaturated with oxygen, soft, approximately neutral with traces of unsoluble substances and with no signs of putrefactive pollution, which means that it roughly corresponds with the parametres of previous older reports. In the further, lower sections its character becomes betamesosaprobic which becomes a better betamesosaprobic as far as above the Kružberk dam, because eutrophization is stabilized, the permanganate number is $3-4 \mathrm{mg} \mathrm{O}_{2} /$ liter and biochemical consumption of oxygen $3 \mathrm{mg} \mathrm{O}_{2} /$ liter. With regard to the fact that in this section the grayling lives and reproduces well, similarly as below the dam, a certain adaptability of the grayling to different hydrochemical types of waters can be demonstrated in these investigations, provided that they are not polluted in such a way as to markedly decrease the oxygen.

Zelinka (1959) summarized the main criteria for the evaluation of the cleanness of grayling waters:

\begin{tabular}{|c|c|c|c|c|c|}
\hline \multirow{2}{*}{$\begin{array}{c}\text { Class of } \\
\text { cleanness }\end{array}$} & \multicolumn{2}{|c|}{$\mathrm{BSK}_{5}$ in $\mathrm{mg} / 1 \mathrm{O}_{2}$} & \multicolumn{2}{|c|}{$\begin{array}{c}\text { Permanganate } \\
\text { number } \mathrm{mg} / 1\end{array}$} & $\mathrm{NH}_{4}$ in $\mathrm{mg} / 1$ \\
\cline { 2 - 5 } & mean & range & mean & range & mean range \\
\hline II. & 1.6 & $2-2.2$ & 3.5 & $2.7-4.6$ & $0.1-0.3$ \\
\hline
\end{tabular}

Sabrobic condition of grayling waters

From the viewpoint of the saprobic condition of water, Zelinka (1955) indicated the alfa-oligo-saprobic condition (IInd class of cleanness) as the section typical for grayling. It includes the gradually disappearing organisms of the cleanest waters, e. g. Planaria gonocephala, abundant is the benthos under stones, especially larvae of the genus Perla. The characteristic species of mayflies is the genus Ecdyonurus. Cladophora glomerata is typical for the algae. Very abundant is moss Fontinalis antipyretica, frequent is waterstarwort (Callitriche verna).

Higher plants are not found before the transition to the further degree of saprobic condition. The lower grayling waters are characterized by pond-weeds and other plants which require sediments and muddy deposits.

Artificial dam lakes changing the composition of water and cooling the lower flows in summer, form a new, specific environment also from the saprobic point of view. Thus also further possibilities for the grayling are changed, its sections are prolonged into the lower parts where it did not live before. It would not be convenient to try and settle the grayling permanently in betaoligosaprobic waters (Ist class) either from the trophic point of view, or for reasons of partly nutritive competition between the grayling and younger trout (and/or char) and with regard to the possibility of late spawning of the grayling.

Zelinka (1955) indicated larvae of stone-flies of the genus Plecoptera, mayflies of the genus Ameletus, Rhitrogena, Baetis, and namely larvae of Liponeura as indicator organisms of betaoligosaprobic waters. 
According to the class of cleannes, the saprobic and trophic degree, the above mentioned author characterizes the grayling to barb zones as follows:

$\begin{array}{ll}\text { Class } & \text { Saprobic zone } \\ \text { II } & \text { good alfa-oligosaprobic } \\ & \text { condition }\end{array}$

Trophic degree mesotrophic condition

Zelinka (1959) classifies the grayling in saprobic valency into the betaoligosprobic zone with a coefficient of occurrence 2 , further into the alfa-oligosaprobic zone with the coefficient 6 , and into the beta-mesosaprobic zone with the coefficient 2 . The maximum occurrence of the species in an optimum saprobic condition is expressed in a pentamerous estimation scale and for the grayling the coefficient of occurrence is 2 . The indicators are for orientation purposes, they cannot be taken dogmatically. It is necessary also to take into account the fact that some sections of rivers below dams provide gradually very good but specific conditions together with various management measures, such as e. g. intensity of fish stocking, regulation of the population, etc.

\section{Grayling locality}

The grayling localities in the biotope are more or less constant. They can temporarily change only during the heaviest floods, of during spawning. The younger fish can be found in the shallows running from the sumps to the fords. Mature graylings are found in fast-running sections without rapids and waterfalls. The grayling can adapt more easily to regulation measures of the flows than the brown trout. In deep flows with a water column of more that $1 \mathrm{~m}$ it should not manage to rise from the bottom following the drifting insects flowing very quickly in the water. Only in some places it stops and gets feed in the close vicinity of the banks. In upland brooks the older fish usually control and defend their localities. In the main current of larger rivers the members of the groups are more tolerant. The majority of grayling localities have a gravel bottom with enough larvae of caddis flies building fine sandy protective capsules. In sections of rivers on the slopes the localities can be found also between the fluttering water plants.

A very important factor for an active choice of locality is the rapidity of the flowing water enabling the catching of imagoes of insect females laying eggs and the collection of small representatives of the fauna. In a normal summer flow (August) the present author together with MVDr. M. Bártík measured the following values in the river Moravice using a current meter:

a) below the ford in a depth of $40 \mathrm{~cm}$ with older graylings $(4+) \quad 0.68 \mathrm{~m} / \mathrm{sec}$.

b) at the end of the washout of the bottom near Karlova Plán in a depth of $50 \mathrm{~cm}$

c) above the broken weir in the main current in a depth of $50 \mathrm{~cm}$

d) near the ford with shoals of grayling fry and yearlings in a depth of $10-20 \mathrm{~cm}$

e) below Roudno near the banks with old graylings of 5-6 years of age

$0.68 \mathrm{~m} / \mathrm{sec}$. $0.48 \mathrm{~m} / \mathrm{sec}$.

$0.25 \mathrm{~m} / \mathrm{sec}$.

$0.24 \mathrm{~m} / \mathrm{sec}$.

In the river Moravice on the slopes the conditions for the grayling are optimum mostly in currents of $0.5 \mathrm{~m} / \mathrm{sec}$. In the lower sections of the river, however, $0.24 \mathrm{~m} / \mathrm{sec}$, is sufficient for older fish. 
During the spring heavy flow of snow water from the Hrubý Jeseník mountains the current in grayling spawning places is as much as $0.7 \mathrm{~m} / \mathrm{sec}$. In the Belá river, tributary of the Váh, it is as much as $1 \mathrm{~m} / \mathrm{sec}$.

\section{Conclusion}

The characteristics of the Czechoslovak grayling biotopes in water sources of different altitudes of mountains, uplands and slopes is not uniform in the chemical composition, thermal regime and saprobic condition, secondarily also in the negative consequences of anthropogenic influences. Therefore, it is necessary to abandon dogmatic generalization of the requirements of the grayling of slope rivers as well as a too narrow comprehension of its ecological valency. Increased populations of this valuable salmonid fish show the present influence of dams increasing their biotopes much farther upland. Reconstruction of the numbers of grayling cannot be done without profound analysis of the complex connections between the abiotic and biotic factors. In the priority task of river fish breeders reviving the varied species composition of the stocking rate approaching the initial conditions and ensuring biological balance, water management has, in the grayling, a bioindicator of the quality of the water environment. A planned protection of the genetic fund, including systematic veterinary care of the fish population, is the way to a permanent multipurpose utilization of water courses for the human population in an intensively utilized landscape.

\section{Charakteristika biotopů lipana podhorního}

Studie analyzuje biotopy lipana podhorního (Thymallus thymallus L., 1758) $v$ povodí Labe a Dunaje $z$ hlediska hydrografie, teplotního režimu, chemických a saprobielních ukazatelů. Výsledky prokazují širší ekologickou valenci tohoto druhu, zatím plně nevyužitou. Lipan má dále význam jako bioindikátor trendu kvality vody toků $\mathrm{v}$ podhưří, na vysočinách a pod přehradami i v nížinách. Charakterizované poměry $\mathrm{v}$ lipaních biotopech jsou východiskem pro veterinární medicínu při zkvalitňování diagnostiky chorob a jejich prevence. Společně s říčním rybářstvím odkryií značné rezervy ekonomické, zájmové a sportovní.

\section{Характеристика биотопов хариуса обыкновенного}

В работе даегся анализ биотопов хариуса обыкновенного (Thymallus thymallus L., 1758) в бассейне рек Лабе и Дунай с точки зрения гидрографии, температурного режима, химических и сапробиотных показателей. Результаты свидетельствуют о более широкой, пока еще не вполне используемой экологической валентности данного вида. Значение хариуса далее сводится к тому, что, будучи биоиндикатором, он отражает тенденции качества воды течений в подгорье, на возвышенностях, под водохранилищами и в низменностях. Характеризуемые условия в биотопах хариусов являюгся исходными данными для ветеринарной медицины при повышении качества диагностики заболеваний и их профилактики. Совместно с речным рыбохозяйством они открывают значительные резервы в экономической, любительской и спортивной областях. 


\section{References}

BAJKOV, A.: Lipani. Př́roda, 20, 1927: 11-14.

BERG, L. S.: Ryby presnych vod SSSR i sopredělnych stran. Moskva, 1948-1949. 1381 pp.

BORNE, M.: Die Fischzucht. Berlin, 1922. 207 pp.

DOLEŽAL, J.: Poznámky rybářské. Praha, 1898.

DYK, V.: Lipanové pásmo v našich řekách. Sbor. ČSAZ, 27, 1954: 261 - 268.

DYK, V.: Die Sommertemperaturen in der Äschenregion. Arch. f. Hydrob., 52, 1956: 388-397.

DYK, V.: Príspevok k poznaniu výskytu, typov a bionomie rýb rieky Belej v povodí Váhu. Sbor. prác o Tatranskom nár. parku, 1, 1958: 75-105.

DYK, V.: Lipan podhorní (Thymallus thymallus Linnaeus, 1758) v různých nadmořských polohách ČSR a Zakarpatské Ukrajiny. SSSR. Biolog. práce (Bratislava), 4/2, 1958: 1-32.

DZUBÁK, M.: in LUKNIŠ, M. et al. Slovensko. Príroda, Bratislava, 1972: 295-303.

FISCHER, A.: Die Äschenregion der Diemel. Münster, 1920. 62 pp.

FRIČ, A.: České ryby a jich cizopasníci. Praha, 1908. 78 pp.

HOLČf́K, J. - HENSEL, K.: Ichtyologická príručka. Bratislava, 1972. 217 pp.

KOSTOMAROV, B. et al.: Studie o znečištění Horní Vltavy. Čes. Budějovice, 1937. 120 pp.

KOMÁREK, J.: Lovy v Karpatech. Praha, 1942. 307 pp.

KUPKA, J.: Prưzkum horní Bečvy. Bull. VÚR Vodňany, 1966: 1-13.

LOSOS, B. - MARVAN, P.: Sbor. VŠZL, Brno, A, 1957: 41-70.

LUKNIS, M. et al.: Slovensko. Príroda. Bratislava, 1972: 295-303.

SABANĚJEV, P. L.: Ryby Rossi. Kijev, 1970. 667 pp.

SEDLMAYER, K.: in KOSTOMAROV, B. České Budějovice, 1937. 120 pp.

TEJČKA, J.: K ekologii lipana. Rybářský věstník, 13, 1937: 102-106

THIENEMANN, A.: Die Süsswasserfische Deutschlands. Stuttgart, 1926. In Handbuch der Binnefischerei Mitteleuropas. $84 \mathrm{pp}$.

VÁLEK, M.: Chemické složení lipanových vod. Čsl. rybář, 1, 1946: 173-174.

VOSTRC̆IL, J. - LOSOS, B.: Sbor. VŠZL Brno, A, 1957: 7-14.

ZELINKA, M.: Př́r. sbor. Ostravského kraje, 11, 2-3, 1950: 1-28.

ZELINKA, M.: Entwicklung der biologischen Verhältnisse in der Talsperre bei Vír während der ersten Jahre nach dem Füllen. Sci. Pap. Inst. Chem. Technol. Prague, Fuel an Water, 4, 1960: 429-276.

ZELINKA, M. - MARVAN, P. - KUBfČEK, F.: Hodnocení čistoty povrchových vod. Opava, 1955: 155. 